\title{
International Conference on Working-Class History
}

\section{Helmut Gruber}

Columbia University Seminar in the History of the Working Class

The 17th International Conference of Historians of the Working-Class Movement (ITH) was held at Linz, Austria from September 8-12. Some 28 countries were represented by the 150 participants. In keeping with the "Status B" accorded to the ITH by UNESCO, ITH is reaching beyond Europe to become truly international. In that spirit, representatives from the U.S., Japan, Mexico, and North Africa were elected to the ITH Executive and simultaneous translations in English/German/French were provided at the sessions.

The two topics on the Conference agenda were: 1) "Working Class Culture and Workers' Cultural Organizations until World War II"; 2) "Regional and Local Working-Class Movements until World War II as Subjects for Research." As most of the papers were distributed to participants before the Conference, oral presentations were restricted to brief extemporaneous amplifications. Papers on both topics were fairly well divided between considerations of theoretical and methodological questions fundamental to the subjects and actual empirical excursions into specific national/topical aspects of the subjects.

Most stimulating among the former was Dieter Langewiesche's (Hamburg) "Politics, Society, Culture: The Problematique of Working-Class Culture and Workers' Cultural Organizations in Germany after World War I." Langewiesche posed a variety of important questions: What is culture in this context?; What is the relationship between leadership and base?; Is there a connection between power/powerlessness and working-class subcultures?; If the everyday life and mentalité of workers is the main focus, what becomes of the party and movement?; Does the uncritical enumeration of working-class cultural accomplishments in effect create a new mystification?; Does the rise of a capitalist "leisure-time industry" both demonstrate inherent weaknesses and the outer limits of workingclass culture?

Among the latter, Helmut Konrad's (Linz) "On Writing the Regional History of the Working-Class Movement in Austria" received the liveliest response. Konrad argued that a narrow geographical focus on regional history also helped to simplify the heterogeneous complexities typically encountered in national studies. 
It is only within the smaller compass, he insisted, that the everyday life of workers from workplace to home life, including the subjectivity of personal experience, could be recreated without lapsing into convenient generalizations. Most challenging was his appeal to make regional history the means of bridging the gap between history and its objects and of thereby transforming the history of the working class into the history of working people. The worker as participant in the writing of his own history was the subject of a report by Sven Lindqvist (Stockholm) on the "Dig Where You Stand" movement in Sweden. Some 200 such local groups of workers are in the process of researching the history of their workplaces and communities by using local records and oral history.

Despite the large number of papers submitted, half of the time was devoted to discussions from the floor. Those took place in an atmosphere of professional harmony which the Austrian hosts of the Conference created with good humor and gemütlichkeit. The opportunity to meet colleagues informally in such an atmosphere and to compare notes on work being done in various countries is vital if the activity of younger historians particularly is to become known beyond its national boundaries.

The ITH decided on the following program for the next two years: September 14-18, 1982: I. "Confessional, Liberal, and Employer-Dependent WorkingClass Organizations until World War II with Special Consideration of the Trade Unions"; II. "Lexicographic Aids for the History of the Working-Class Movement (history, present situation, perspectives)." September, 1983: I. "The Working-Class Movement and the Question of Peace, 1917-1939'; II. "Spontaneity and Organization in the Working-Class Movement as Methodological Problem."

Anyone interested in presenting a paper at Linz in 1982 should contact the writer (425 Riverside Drive, New York, N.Y. 10025) by March 1, 1982. The ITH provides for room and board at the Conference. A partial subvention of travel costs is also possible. This year only two historians from the U.S. participated at Linz. Hopefully we can break out of such superpower provincialism next year. 